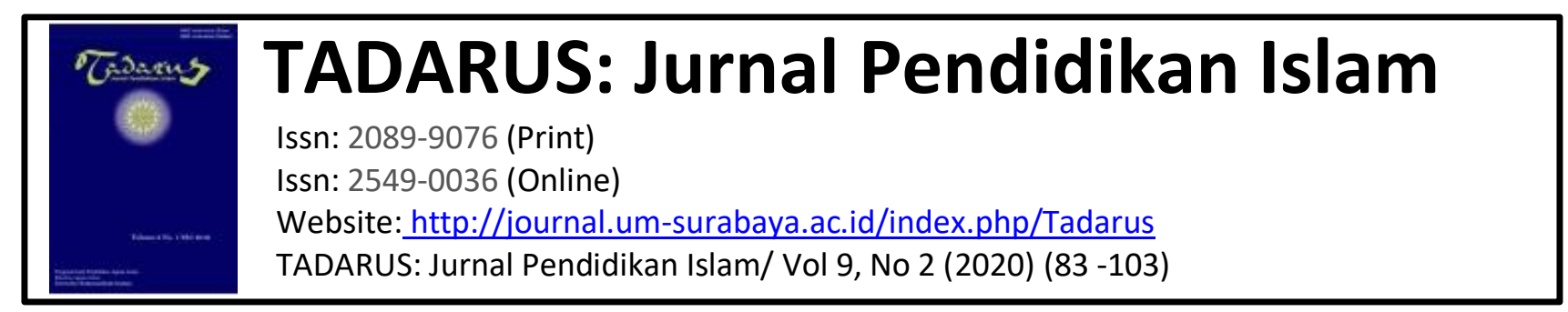

\title{
IMPLEMENTASI STRATEGI THINK, TALK, WRITE DALAM \\ MENINGKATKAN KEAKTIFAN BELAJAR SISWA PADA \\ PEMBELAJARAN AL-ISLAM DI SMP MUHAMMADIYAH PONDOK MODERN PACIRAN LAMONGAN
}

\author{
${ }^{1}$ Zainal Arifin, ${ }^{2}$ Riza Firmansyah \\ ${ }^{1}$ zainalarifin102018@gmail.com, 2elatsaryrz@gmail.com
}

\begin{abstract}
Abstrak
Seorang guru dikatakan sebagai guru efektif apabila ia mampu mengubah Strategi, Metode, dan Teknik dalam mengajar agar tidak terkesan membosankan sehingga siswa terkesan pasif di dalam kelas. Untuk itu guru harus mempunyai cara atau metode yang tepat dalam menyampaikan suatu pelajaran salah satunya adalah dengan strategi Think, Talk, Write (TTW). Rumusan masalah dalam penelitian ini adalah, Pertama, Bagaimana implementasi strategi Think, Talk, Write di SMP Muhammadiyah Pondok Modern Paciran Lamongan, Kedua, Sejauh mana penerapannya dalam Meningkatkan Keaktifan belajar siswa kelas X-11 pada pembelajaran AlIslam di SMP Muhammadiyah Pondok Modern Paciran Lamongan. Pendekatan dalam penelitian ini adalah deskriptif - kualitatif dengan menggunakan tiga teknik pengumpulan data, yakni observasi, interview, dan dokumentasi, dan dengan teknik análisis induksi, deduksi, dan komparasi. Hasil penelitian ini menyimpulkan bahwa, Pertama, Implementasi strategi Think, Talk, Write di SMP Muhammadiyah Pondok Modern Paciran Lamongan sudah berjalan cukup baik, karena dalam penerapannya tidak ada kendala - kendala atau problem - problem, serta adanya penerapan strategi Think, Talk, Write memiliki kontribusi atau peran terhadap pendidikan anak di SMP Muhammadiyah Pondok Modern Paciran Lamongan, terutama dalam membantu kegiatan belajar mengajar dikelas. Kedua, Adapun implementasi dari strategi Think, Talk, Write dalam meningkatkan keaktifan belajar siswa, adalah dengan penggunaan berbagai metode pengajaran yang dilakukan oleh guru sehingga dapat memotivasi siswa dalam belajar, membuat siswa lebih memperhatikan pelajaran, membantu proses pembelajaran interaktif menyenangkan antara guru dan murid, sehingga memudahkan menerima materi pelajaran.
\end{abstract}

Kata kunci : Strategi, Think, Talk, Write dan Al-Islam 


\section{Pendahuluan}

Belajar mengajar adalah suatu kegiatan yang bernilai edukatif. Nilai edukatif mewarnai interaksi yang terjadi antara guru dan anak didik. Interaksi yang bernilai edukatif di karenakan kegiatan belajar mengajar yang dilakukan di arahkan untuk mencapai tujuan tertentu yang telah dirumuskan sebelum pengajaran dilakukan. Guru dengan sadar melakukan atau merencanakan kegiatan pengajarannya secara sistematis dengan memanfaatkan segala sesuatnya guna kepentingan pengajaran. ${ }^{1}$

Pembelajaran merupakan suatu proses yang komplek dan melibatkan berbagai aspek yang saling berkaitan. Oleh karena itu untuk menciptakan pembelajaran yanag kreatif, dan menyenangkan di perlukan berbagai ketrampilan membelajarkan atau ketrampilan mengajar. Setiap pengajar mempunyai cara tersendiri dalam melaksanakan tugasnya sebagai pengajar. Hal ini dapat dimengerti karena setiap pengajar mempunyai kapasitas mengajar yang berbeda-beda. Seorang pengajar memerlukan keahlian dalam memilih dan melaksanakan cara mengajar yang terbaik agar ilmu pengetahuan tersebut dapat diberikan dengan baik. Pendidikan pada dasarnya adalah usaha sadar untuk menumbuh kembangkan potensi sumber daya manusia peserta didik dengan cara mendorong dan memfasilitasi kegiatan belajar mereka.

Menurut John S. Brubacher berpendapat bahwa pendidikan adalah proses pengembangan potensi, kemampuan, dan kapasitas manusia yang mudah dipengaruhi oleh kebiasaan, kemudian disempurnakan dengan kebiasaan-kebiasaan yang baik, didukung dengan alat (media) yang disusun sedemikian rupa, sehingga pendidikan dapat digunakan untuk menolong orang lain atau dirinya sendiri dalam mencapai tujuan-tujuan yang telah ditetapkan. ${ }^{2}$

Selamanya pendidikan tetap menjadi alternatif dalam mengembangkan dan meningkatkan sumber daya manusia, utamanya dalam mempersiapkan generasi mendatang agar mampu menjawab tentang perubahan zaman melalui proses belajar mengajar yang merupakan dua konsep yang tidak dapat dipisahkan satu dengan yang lainnya, terutama dalam praktiknya di sekolah, dan untuk mempersiapkan generasi yang mampu menjawab tentang perubahan zaman yang serba canggih ini, perlu adanya perubahan dan perkembangan dalam proses belajar mengajar.

\footnotetext{
${ }^{1}$ Syaiful Bahri Djamarah, strategi belajar mengajar, (Jakarta: Rineka Cipta, 1995), 1

${ }^{2}$ Wiji Suwarno, Dasar-dasar Ilmu Pendidikan, (Yogyakarta: AR-RUZZ Media, 2006), 20
} 
Belajar adalah suatu proses yang kompleks yang terjadi pada diri setiap orang sepanjang hidupnya. Proses belajar itu terjadi karena adanya intruksi antara seseorang dengan lingkungannya. Oleh karena itu belajar dapat terjadi kapan saja dan dimana saja. Interaksi yang terjadi selama proses belajar tersebut dipengaruhi oleh lingkungannya, yang antara lain, murid, guru, materi pelajaran dan berbagai sumber belajar dan fasilitas (komputer, laboratorium, pusat sumber belajar) dan lain sebagainya. ${ }^{3}$

Agar terjadi interaksi antara siswa dan guru dalam proses belajar mengajar yang menyenangkan dan dapat memotivasi siswa, guru dituntut untuk merancang materi pembelajaran yang dapat membangkitkan semangat belajar siswa, telah kita ketahui kasus-kasus yang terjadi di sekolah-sekolah yang ada kebanyakan malas belajar dan semangat mencari ilmu sirna begitu saja, hal itu terjadi karena kurang adanya proses belajar mengajar yang kreatif. Dan salah satu alternatif yang bisa dilakukan adalah menciptakan pembelajaran yang menyenangkan, kreatif, efektif dan efisien bagi siswa.

Metode pembelajaran yang berkembang saat ini banyak bentuknya, antara yang satu dengan yang lain mempunyai karakteristik yang berbeda-beda. ${ }^{4}$ Akan tetapi walaupun banyak bentuknya masih tetap diterapkan untuk mencapai tujuan yang sama yaitu untuk memotivasi belajar siswa sehingga tercipta proses belajarmengajar yang kondusif dan menyenangkan. Metode pembelajaran merupakan hal yang mutlak dilakukan dalam rangka peningkatan mutu pendidikan. Proses pendidikan bisa berjalan efektif, apabila metode pembelajaran yang diterapkan di kelas mampu menumbuhkan gairah siswa untuk belajar.

Pembelajaran merupakan suatu proses yang komplek dan melibatkan berbagai aspek yang saling berkaitan. Oleh karena itu untuk menciptakan pembelajaran yang kreatif, dan menyenangkan diperlukan berbagai ketrampilan membelajarkan atau ketrampilan mengajar. Dalam sistem pendidikan, guru memegang peranan sentral dalam proses pembelajaran. Untuk itu guru harus mempunyai cara atau metode yang tepat dalam menyampaikan suatu pelajaran salah satunya adalah dengan strategi Think, Talk, Write (TTW).

\footnotetext{
${ }^{3}$ Azhar Arsyad, Media Pembelajaran, (Jakarta: Raja Grafindo Persada, 2007), 1

${ }^{4}$ Najib Sulhan, Pembangunan Karakter pada Anak, Manajemen Pembelajaran Guru Menuju Sekolah Efektif, (Surabaya: Intelektual Clib, 2006), 5
} 
Seorang guru dikatakan sebagai guru efektif apabila ia mampu mengubah Strategi, Metode, dan Tehnik dalam mengajar agar tidak terkesan membosankan sehingga siswa terkesan pasip di dalam kelas. Strategi Think, Talk, Write (TTW) digunakan untuk merangsang keterlibatan siswa dalam berpikir dan berdialog dengan dirinya sendiri setelah proses membaca kemudian berbicara dan membagi ide dengan temannya. Pembelajaran ini dimulai dengan berpikir melalui bahan bacaan. Strategi ini memfasilitasi kemampuan latihan berbahasa secara lisan dan menulis bahasa dengan lancar yang berdasarkan pada pemahaman bahwa belajar adalah sebuah perilaku sosial. ${ }^{5}$

Mengajar bukan semata persolan menceritakan, belajar bukanlah konsekuensi otomatis dari penuangan informasi kedalam benak siswa. Belajar memerlukan keterlibatan mental dan kerja siswa sendiri. Penjelasan dan penerangan semata tidak akan membuahkan hasil belajar yang langgeng. Menurut Melvin, ${ }^{6}$ hanyalah belajar aktif. Belajar aktif sangat di perlukan oleh peserta didik untuk mendapatkan hasil belajar yang maksimal, ketika peserta didik belajar dengan aktif berarti mereka yang mendominasi aktivitas pembelajaran. Dengan ini mereka mereka secara aktif menggunakan otak baik untuk menemukan ide pokok dari materi pelajaran, memecahkan persoalan atau mengaplikasikan apa yang baru mereka pelajari kedalam suatu persoalan yang ada dalam kehidupan nyata. Dengan belajar aktif ini, siswa di ajak untuk turut serta dalam semua proses pembelajaran, tidak hanya mental akan tetapi melibatkan fisik. Dengan ini siswa akan merasakan suasana yang lebih menyenangkan. ${ }^{7}$

Oleh karena itu, tugas utama guru adalah mengkondisikan siswa agar belajar aktif bukan sebaliknya (guru aktif dan siswa pasif) hal ini sesuai dengan salah satu prinsip dalam kurikulum 2006 (KTSP) yaitu belajar untuk membangun dan menemukan jati diri melalui PAKEM (pembelajaran aktif, kreatif, efektif dan menyenangkan) untuk dapat mewujudkan hal tersebut, guru seyogyanya mengetahui bagaimana cara siswa belajar dan menguasai berbagai cara membelajarkan siswa.

Setiap siswa memiliki gaya belajar yang berbeda. Dalam buku "Quantum

\footnotetext{
${ }^{5}$ http://www.mtsd.k12.wi.us/NTSD/Distric/ela-curikulum03/writing/thinktalkwrite.html.

${ }^{6}$ Melvin L. Silberman, Active Learning, (Bandung: Nusa Media, 2004), 1

${ }^{7}$ Hisyam Zaini, dkk, Strategi Pembelajaran Aktif, (Yogyakarta: CTSD, 2007), 2
} 
Leraning yang di tulis oleh Bobbi De Porter Dan Mike Hermaeki ${ }^{8}$ disebutkan bahwa ada dua kategori utama tentang bagaimana siswa belajar. Pertama, bagaimana siswa menyerap informasi dengan mudah (modalitas) dan kedua, cara siswa mengatur dan mengolah informasi tersebut (dominasi otak) sedangkan untuk dapat membelajarkan siswa sesuai dengan cara dan gaya belajar mereka. Guru harus menguasai berbagai macam pendekatan, Model, Strategi, Metode dan Taktik dalam pembelajaran serta dapat menggunakannya dengan tepat. Oleh karena itu, dalam memilih metode dan tekhnik pembelajaran haruslah memperhatikan kondisi siswa, sifat materi bahan ajar, fasilitas dan media serta kondisi guru.

Menurut Huinker dan Laughlin bahwa Strategi membangun secara tepat untuk berfikir dan merefleksikan dalam mengorganisasikan ide-ide serta mengetes ide tersebut sebelum siswa dimintak untuk menulis. Dalam kegiatan pembelajaran AlIslam sering ditemui bahwa ketika siswa diberikan tugas tertulis, siswa selalu mencoba untuk langsung memulai menulis jawaban. Walaupun hal itu bukan sesuatu yang salah. Namun, akan lebih bermakna jika dia terlebih dahulu melakukan kegiatan berpikir, merefleksikan dan menyusun ide-ide, serta menguji ide-ide itu sebelum memulai menulisnya. Strategi Think-Talk-Write yang dipilih pada penelitian ini dibangun dengan memberikan waktu kepada siswa untuk melakukan kegiatan tersebut (berpikir, merefleksikan dan untuk menyusun ide-ide, dan menguji ide-ide itu sebelum menulisnya).

Menurut Silver dan Smith, peranan dan tugas guru dalam usaha mengefektifkan penggunaan Strategi Think-Talk-Write adalah mengajukan dan menyediakan tugas yang memungkinkan siswa terlibat secara aktif berpikir, mendorong dan menyimak dengan hati-hati ide-ide yang dikemukakan siswa secara lisan dan tertulis, mempertimbangkan dan memberi informasi terhadap apa yang digali siswa dalam diskusi, serta memonitor, menilai, dan mendorong siswa untuk berpartisipasi secara aktif. Tugas yang disiapkan diharapkan dapat menjadi pemicu siswa untuk bekerja secara aktif yaitu soal-soal yang mempunyai jawaban divergen atau open ended task. ${ }^{9}$

Aktivitas belajar merupakan sesuatu yang sangat penting dalam proses belajar, karena pada prinsipnya belajar adalah berbuat untuk mengubah tingkah laku. Dalam setiap proses belajar siswa selalu menampakkan keaktifan yang beranekaragam

\footnotetext{
${ }^{8}$ Bobbi De Porter dan Mike Hermaeki, Quantum learning, (Bandung: Kaifa, 2002), 110

${ }^{9}$ http://www.mtsd.k12.wi.us/NTSD/Distric/ela-curikulum03/writing/thinktalkwrite.html.
} 
bentuknya mulai dari kegiatan fisik yang mudah kita amati sampai kegiatan fisik yang susah diamati. Kegiatan fisik bisa berupa membaca, mendengar, menulis, berlatih keterampilan-keterampilan dan sebagainya. Sedangkan psikis seperti menggunakan khasanah pengetahuan yang dimiliki dalam memecahkan masalah yang dihadapi, membandingkan satu konsep dengan yang lain, menyimpulkan hasil percobaan dan kegiatan psikis yang lain. ${ }^{10}$

Dalam proses pembelajaran banyak sekali metode pembelajaran yang dapat digunakan oleh guru dalam proses belajar mengajar antara lain yaitu: metode ceramah, Tanya jawab, diskusi, demontrasi dan lain-lain, akan tetapi tanpa adanya variasi dalam metode pembelajaran yang di gunakan, biasanya siswa akan merasa bosan, jenuh kurang bergairah bahkan mengantuk hal ini sering kita temui dalam materi pelajaran yang cenderung bersifat teoritis dan hafalan untuk mengantisipasi terjadinya hal tersebut diperlukan ketrampilan dan keaktifan guru dalam mengelolah metode yang di gunakan misalnya, guru ingin mengajak siswa belajar dengan mengasah kemampuan bertanya dan menjawab pertanyaan maka metode yang di gunakan adalah metode Tanya jawab tetapi tidak dapat dipungkiri bahwa tidak semua siswa dapat aktif berpatisipasi dengan menggunakan metode Tanya jawab ini hanya siswa yang pandai saja yang aktif berpartisipasi dalam kelas, sedangkan siswa yang memiliki kemampuan sedang hanya sebagai penonton saja, supaya metode Tanya jawab yang di gunakan dapat menarik perhatian siswa dan mengajak seluruh siswa berperan aktif dalam proses pembelajaran maka di perlukan variasi yang dapat di gunakan oleh guru yaitu strategi Thik, Talk, Write (TTW).

\section{Metode Penelitian}

Dalam penelitian ini, peneliti menggunakan penelitian kualitatif deskriptif. Penelitian kualitatif deskriptif adalah suatu fenomena penelitian yang bertujuan untuk menggambarkan keadaan-keadaan atau status fenomena sesuatu yang terjadi yang terdapat dalam arti, baik dari kata-kata tertulis maupun lisan dari orang-orang yang menjadi subjek penelitian. Data yang dikumpulkan adalah berupa kata-kata atau gambar dan bukan angka-angka. Data tersebut mungkin berasal dari naskah, wawancara, catatan lapangan, foto, video tape, dokumen pribadi, catatan atau memo,

\footnotetext{
${ }^{10}$ Dimiyati, Belajar dan pembelajaran, (Jakarta: Rineka Cipta, 1999), 45
} 
dan dokumen resmi lainnya. ${ }^{11}$ Dan penelitian ini termasuk dalam metode deskriptif dengan menggunakan pendekatan survey sejenis school survey. Metode deskriptif adalah suatu metode dalam meneliti status kelompok manusia, serta kondisi suatu sistem pemikiran ataupun suatu kelas tertentu tentang suatu peristiwa yang terjadi pada masa sekarang. ${ }^{12}$ Penelitian kualitatif berusaha menampilkan secara holistic (utuh) yang membutuhkan kecermatan dalam pengamatan sehingga kita dapat memahami secara menyeluruh hasil penelitian, disamping itu dalam penelitian kualitatif ini peneliti harus terjun langsung ke lapangan guna memperoleh data yang peneliti butuhkan.

Dalam penelitian ini keaktifan belajar itu hal yang tampak dalam perilaku yang di lakukan oleh siswa dalam proses belajar mengajar, maksudnya adalah dalam proses belajar mengajar siswa. ${ }^{13}$ dan di samping itu siswa juga sangat antusias dalam menanggapi setiap pertanyaan yang di berikan oleh guru atau siswa yang lainnya, dan kegitan belajar mengajar ini memerlukan kerjasama dan keaktifan dalam tiga tahap sekaligus yaitu berpikir, berbicara atau berdiskusi dan menulis (meranngkum) di setiap kelompok masing-masing.

\section{A. HASIL PENELITIAN DAN PEMBAHASAN}

\section{Strategi Think, Talk, Write}

Strategi Think, Talk, Write (TTW) yaitu strategi yang di gunakan untuk merangsang keterlibatan siswa dalam berpikir dan berdialog dengan dirinya sendiri setelah proses membaca kemudian berbicara dan membagi ide dengan temannya. Pembelajaran ini dimulai dengan berpikir melalui bahan bacaan. Secara harfiah strategi pembelajaran Think, Talk, Write adalah strategi yang memfasilitasi latihan berbahasa secara lisan dan menulis bahasa tersebut dengan lancar. Strategi ThinkTalk-Write mendorong siswa untuk berfikir, berbicara, dan kemudian menuliskan berkenaan dengan suatu topik ${ }^{14}$, jadi dengan adanya strategi pembelajaran yang menggunakan tiga tahapan yaitu: berfikir, berbicara dan menulis, dimana seorang guru memberikan stimulus kepada siswa melalui strategi ini yang di mulai dari membaca bacaan sambil berfikir untuk menemukan ide pokok kemudian akan di diskusikan sesama temanya dan di dalam proses ini siswa di haruskan untuk siap

\footnotetext{
${ }^{11}$ Lexy, J. Moleong, Metodologi Penelitian Kualitatif, (Bandung: Remaja Rosda Karya, 2007), 6

${ }^{12}$ Moh. Nasir, Metodologi Penelitian, cet.3 (Jakarta: Ghalia Indonesia, 1998), 63

${ }^{13}$ Deddy Mulyana, Metodologi Penelitian Kualitatif, (Bandung: Remaja Rosda Karya, 2002 ), 23

${ }^{14}$ http://www.mtsd.k12.wi.us/MTSD/District/ela-curriculum-03/writing/think_talk_write.html
} 
menjawab, mengomentari sekaligus memberikan petanyaan balik kepada teman lainya. jadi bisa diterjemahkan secara bebas sebagai kesadaran berpikir, berpikir tentang apa yang dipikirkan dan bagaimana proses berpikirnya, yaitu aktivitas individu untuk memikirkan kembali apa yang telah terpikir serta berpikir dampak sebagai akibat dari buah pikiran terdahulu.

Sharples \& Mathew mengemukakan pendapat bahwa metakognitrif dapat dimanfaatkan untuk menerapkan pola pikir pada situasi lain yang dihadapi. ${ }^{15}$ Kemampuan metakognitif atau berfikir setiap individu akan berlainan, tergantung dari variabel meta kognitif, yaitu kondisi individu, kompleksitas, pengetahuan, pengalaman, dan manfaat, Perhatikan hasil penelitian Jack Canfield ${ }^{16}$, untuk kita simak dan renungkan, bahwa seorang anak yang masih polos-natural, setiap hari biasa menerima 460 komentar negatif dan komentar positif dari orang yang lebih tua dalam kehidupannya. Akibatnya sungguh mengejutkan, anak yang pada awalnya secara alami penuh keyakinan, keberanian, suka tantangan, ingin mencoba, ingin tahu dengan pengaruh komunikasi negatif yang lebih dominant dari orang sekelilingnya, ternyata lama kelamaan keyakinannya terguncang dan rasa percaya dirinya menurun, sehingga dia tumbuh menjadi penakut, pemalu, ragu-ragu, menghindar, membiarkan, dan cemas. Dampak selanjutnya pada waktu bersekolah, belajar menjadi beban dan rasa percaya dirinya berkurang. Makin lama ia makin dewasa, pribadinya berpola negative, seperti pesimis, mudah menyerah, dikendalikan keadaan, prasangka, pembenaran, menimpakan kesalahan, dan sibuk dengan alasan. Berbeda dengan individu yang memiliki pribadi positif, yaitu optimis, mengendalikan keadaan, ada kebebasan memilih, punya alternative, partisipasi, dan mau memperbaiki diri.

Sebagai guru, tentunya akan berhadapan dengan siswa yang berkepribadian negative seperti di atas dan tentunya tidak untuk dibiarkan karena profesi guru adalah amanat. Bagaimanakah menghadapi siswa dengan pola pribadi seperti irtu? Caranya antara lain dengan cara tidak memvonis, katakana "saya ..." bukan katanya, jangan sungkan untuk apologi jika kesalahan, tumbuhkan citra positif, bersikap mengajak dan bukan memerintah, dan jaga komunikasi non verbal (eksprsi wajah, nada suara, gerak tubuh, dan sosok panutan). Mengapa demikian? Karena

\footnotetext{
${ }^{15}$ Mathews, J. M, Using A Studio-Based Pedagogy to Engage Students in The Design of Mobile-Based Media, English Teaching: Practice and Critique, 9 (1) 2010, 87-102.

${ }^{16}$ Siccone, Frank, and Jack Canfield, 101 Ways to Develop Student Self-esteem and Responsibility: The Power to Succeed in School and Beyond. Vol. 2. Allyn \& Bacon, 1992.
} 
cara berkomunikasi akan langsung berkenaan dengan akal dan rasa, yang selanjutnya mempengaruhi poses pembelajaran. Dalam belajar apapun, belajar efektif (sesuai tujuan) semestinya bermakna. Agar bermakna, belajar tidak cukup dengan hanya mendengar dan melihat tetapi harus dengan melakukan aktivitas (membaca, bertanya, menjawab, berkomentar, mengerjakan, mengkomunikasikan, presentasi, diskusi). Dalam bahasa Sunda ada pepatah "pok-pek-prak" yang berarti bahwa belajar mempunyai indikator berkata-pok (bertanya-menjawab-diskusi, presentasi). Mencoba-pek (menyelidiki, meng-identifikasi, menduga, menyimpulkan, menemukan) dan melaksanakan-prak (mengaplikasikan, menggunakan, memanfaatkan, mengembangkan).

Tokoh pendidikan nasional Ki Hajar Dewantoro mengemukakan tiga prinsip pembelajaran ing ngarso sung tulodo (jadi pemimpin-guru jadilah teladan bagi siswanya),"Ing Madyo Mangun Karso" (dalam pembelajaran membangun ide siswa dengan aktivitas sehingga kompetensi siswa terbentuk), "Tut Wuri Handayani" (jadilah fasilitator kegiatan siswa dalam mengembangkan life skill sehingga mereka menjadi pribadi mandiri). Dengan perkataan lain, pembelajaran adalah solusi tepat untuk pelaksanaan kurikulum 2006, dan bukan dengan kegiatan mengajar. Selanjutnya, Vernon A Madnesen dan san Peter Sheal mengemukakan bahwa ${ }^{17}$ kebermaknaan belajar tergantung bagaimana belajar. Jika belajar hanya dengan membaca kebermaknaan bisa mencapai 10\%, dari mendengar 20\%, dari melihat $30 \%$, mendengar dan melihat 50\%, mengatakan-komunikasi mencapai $70 \%$, dan belajar dengan melakukan dan mengkomunikasikan bisa mencapai 90\%.

\section{Pelaksanaan Strategi Think, Talk, Write}

Al-Islam merupakan salah satu mata pelajaran pendidikan agama islam yang ada di SMP Muhammadiyah Pondok Modern Paciran Lamongan, yang tujuan pembelajarannya adalah menanamkan taqwa dan akhlak serta menegakkan kebenaran dalam rangka membentuk manusia yang berpribadi dan berbudi luhur, serta menumbuhkan pola kepribadian manusia yang bulat melalui latihan kejiwaan, kecerdasan otak, penalaran, perasaan dan indera menurut ajaran Agama Islam. Dengan adanya penggunaan Strategi Think, Talk, Write ini, diharapkan dapat melatih siswa untuk mengkontruksikan pengetahuannya sendiri sehingga pemahaman siswa menjadi lebih baik, sehingga dapat mencapai tujuan

\footnotetext{
${ }^{17}$ Sheal, P, How to Develop and Present Staff Training Courses (Kogan Page/Nichols Publishing, New
} York, 1989). 
pembelajaran yang diinginkan yaitu tercapainya tujuan pembelajaran Al-Islam, karena pada dasarnya strategi ini mengajak siswa agar dalam belajar siswa tidak hanya duduk dan mendengarkan saja akan tetapi siswa harus membaca, berfikir, berkomunikasi (berbicara)dan menyimpulkan, maka akan dapat meningkatkan kemungkinan mereka untuk semakin mampu mengingat dan menyimpan informasi yang sudah diberikan. Untuk itu yang terbaik bagi guru Al-Islam adalah menambah latihan pelajaran Al-Islam dalam berbagai cara yang berbeda, seperti dengan penggunaan metode dan stategi yang bermacam-macam.

Bagi pihak sekolah penerapan strategi Think, Talk, Write tidak mengalami problem atau kendala yang berarti strategi Think, Talk, Write (berfikir, berbicara, menulis) sudah memberikan hasil yang sangat memuaskan di samping itu strategi ini juga menggunakan tiga aktifitas, akan tetapi semua itu akan lebih lengkap jika diberikan sebuah variasi dalam Metode dan Strategi belajar yang digunakan oleh guru akan dapat menjadikan siswa lebih semangat dalam belajarnya. Think, Talk, Write yang di berikan oleh guru tidak menjadikan hal yang menjenuhkan bagi siswa akan tetapi menjadi hal-hal yang lebih kritis dan menyenangkan.

Adanya strategi Think, Talk, Write sangat bermanfaat bagi sekolah khususnya bagi para guru untuk dapat meningkatkan keaktifan anak, membantu sekaligus proses pembelajaran yang interaktif dan tidak membosankan karena dilakukan dengan cara atau metode yang menggunakan tiga kegiatan (berfikir, berbicara dan menulis), sudah berjalan cukup baik, dengan maksud sudah diterapkan dengan baik karena dalam pelaksanaannya, terutama dari guru yang menerapkan strategi Think, Talk, Write tidak mengalami kendala-kendala yang ditimbulkan oleh para siswa. Adanya strategi think, talk, write di SMP Muhammadiyah Pondok Modern Paciran Lamongan sangat bermanfaat bagi sekolah karena strategi think, talk, write dapat meningkatkan kecerdasan dan kualitas pendidikan dengan membantu menciptakan proses pembelajaran yang interaktif dan menyenangkan, bagi guru akan memperoleh pengalaman dalam merancang dan melaksanakan pembelajaran secara inovatif sehingga dengan sendirinya akan meningkatkan motivasi guru dalam menjalankan tugasnya secara lebih professional, serta meningkatkan motivasi siswa dalam upaya mengembangkan keaktifan belajarnya agar lebih optimal.

Berdasarkan hasil wawancara (interview) penulis dengan Bapak Husnul Abid selaku guru AL Islam di SMP Muhammadiyah Pondok Modern Paciran Lamongan ini menyatakan bahwa strategi pembelajaran Think, Talk, Write ini diterapkan mulai 
tahun ajaran baru 2017 pada Kelas VII, VIII, dan IX, dengan melihat keluhan dan melihat kurangnya minat siswa untuk mempelajari materi tentang Al-Islam akhirnya guru mata pelajaran Al Islam ini berusaha untuk memberi motivasi dan berusaha menciptakan suasana belajar yang menyenangkan yaitu dengan menerapkan strategi pembelajaran Think, Talk, Write, yang mana strategi Think, Talk, Write, ini merupakan sebuah inovasi pembelajaran saat ini, yang dapat menyampaikan pengajaran secara langsung kepada siswa melalui cara berinteraksi dalam mata pelajaran yang telah dikemas dalam bentuk membaca, berfikir, berdialog dengan sesama teman dan menuangkan hasil dialog dalam tulisan yang sesuai dengan pemikiran siswa masing-masing. Dan dalam memberikan motivasi bagi siswa, guru memberikannya dengan jalan memberi saran (nasihat) dan kritikan yang tentunya bersifat membangun baik itu berada di dalam maupun diluar kelas dengan tujuan supaya siswa mampu menerima dan melaksanakan hasil belajar secara maksimal pada kehidupan mereka sendiri. Dalam hal ini berkaitan dengan pedoman keterampilan hidup (life skill education) pada pola kehidupan lingkungan, sekolah dan masyarakat pada umumnya.

Dalam pelaksanaan pembelajaran Al-Islam dengan menggunakan strategi Think, Talk, Write, tentunya seorang guru memberikan jalan belajar bagi siswa dengan memberikan keleluasaan dalam belajar menurut kondisi masing-masing siswa. Hal ini digunakan agar siswa tidak mengalami kejenuhan maupun kebosanan dalam belajar, karena hal tersebut akan menjadi penghambat dalam proses pembelajaran, tentunya dengan adanya sebuah pengawasan yang tepat dan konsisten dari guru yang bersangkutan, sehingga siswa di kelas akan mampu mengembangkan nilai-nilai kreativitas secara luas menurut kemampuan pola pikir siswa tersebut.

\section{Keaktifan Belajar Siswa Pada Pembelajaran Al-Islam}

Dalam proses pembelajaran Al-Islam dengan menggunakan strategi Think, Talk, Write ini siswa turut aktif berpartisipasi. Hal itu terlihat ketika perhatian siswa dalam mengikuti proses belajar mengajar. Pada saat berlangsungnya proses pembelajaran dengan menggunakan strategi Think, Talk, Write semua siswa mengikuti proses belajar mengajar secara baik dan penuh kedisiplinan. Siswa dapat dikatakan disiplin yaitu dengan menilai dan melihat siswa dalam beraktivitas, siswa dalam mengerjakan tugas-tugas yang diberikan kepada guru, setiap siswa memiliki aktivitas yang tinggi dalam mengerjakan tugas-tugas yang telah diberikan guru secara tertulis, dan semua siswa dalam menyelesaikan tugasnya masing-masing telah 
berpartisipasi secara aktif.

Pembelajaran yang aktif dimaksudkan untuk mengoptimalkan penggunaan semua potensi yang dimiliki oleh anak didik, sehingga semua anak didik dapat mencapai hasil belajar yang memuaskan sesuai dengan karakteristik pribadi yang mereka miliki. Disamping itu pembelajaran aktif juga dimaksudkan untuk menjaga perhatian siswa atau anak didik agar tetap tertuju pada proses pembelajaran. Beberapa penelitian membuktikan bahwa perhatian anak didik berkurang bersamaan dengan berlalunya waktu. Penelitian Pollio (1984) ${ }^{18}$ menunjukkan bahwa siswa dalam ruang kelas hanya memperhatikan pelajaran sekitar $40 \%$ dari waktu pembelajaran yang tersedia. Sementara penelitian McKeachie $(1986)^{19}$ menyebutkan bahwa dalam sepuluh menit pertama perthatian siswa dapat mencapai 70\%, dan berkurang sampai menjadi $20 \%$ pada waktu 20 menit terakhir. Kondisi tersebut di atas merupakan kondisi umum yang sering terjadi di lingkungan sekolah. Hal ini menyebabkan seringnya terjadi kegagalan dalam dunia pendidikan kita, terutama disebabkan anak didik di ruang kelas lebih banyak menggunakan indera pendengarannya dibandingkan visual, sehingga apa yang dipelajari di kelas tersebut cenderung untuk dilupakan. ${ }^{20}$ Sebagaimana yang diungkapkan Konfucius:

a. Apa yang saya dengar, saya lupa.

b. Apa yang saya lihat, saya ingat.

c. Apa yang saya lakukan, saya paham.

Sedangkan Mel Silberman ${ }^{21}$ memodifikasi dan memperluas pernyataan

Confucius di atas menjadi apa yang disebutnya dengan belajar aktif, yaitu :

a. Apa yang saya dengar, saya lupa.

b. Apa yang saya dengar dan lihat, saya ingat sedikit.

c. Apa yang saya dengar, lihat dan tanyakan atau diskusikan dengan beberapa teman lain, saya mulai paham.

d. Apa yang saya dengar, lihat, diskusikan dan lakukan, saya memperoleh

\footnotetext{
${ }^{18}$ Pollio, H. R., Fabrizi, M. S., Sills, A., \& Smith, M. K, Need metaphoric comprehension take longer than literal comprehension?, Journal of Psycholinguistic Research, 13 (3), 195-214.

${ }^{19}$ McKeachie, Wilbert James, Teaching and Learning in The College Classroom: A review of The Research Literature. Vol. 86, University of Michigan Press, 1986.

${ }^{20} 5 \mathrm{Httpp} / /$ Educare-e-fkipunla. Net/index. Php. 22 juli 2019

${ }^{21}$ Silberman, Mel, Developing Interpersonal Intelligence in The Workplace, Industrial and Commercial Training 2001.
} 
pengetahuan dan keterampilan.

e. Apa yang saya ajarkan pada orang lain, saya kuasai.

Pernyataan-pernyataan tersebut menekankan pada pentingnya belajar aktiv agar apa yang dipelajari di bangku sekolah tidak menjadi suatu hal yang sia-sia. Ungkapan tersebut sekaligus menjawab permasalahan yang sering dihadapi dalam proses pembelajaran, yaitu tidak tuntasnya penguasaan anak didik terhadap materi pembelajaran. Ada beberapa alasan yang dikemukakan mengenai penyebab mengapa kebanyakan orang cenderung melupakan apa yang mereka dengar. Salah satu jawabannya adalah karena adanya perbedaan antara kecepatan bicara guru dengan tingkat kemampuan siswa mendengarkan apa yang disampaikan guru. Kebanyakan guru berbicara sekitar 100-200 kata per menit, sementara anak didik hanya mampu mendengarkan 50-100 kata per menitnya (setengah dari apa yang dikemukakan guru), karena siswa mendengarkan pembicaraan guru sambil berpikir. Kerja otak manusia tidak sama dengan tape recorder yang mampu merekam suara sebanyak apa yang diucapkan dengan waktu yang sama dengan waktu pengucapan. Otak manusia selalu mempertanyakan setiap informasi yang masuk ke dalamnya, dan otak juga memproses setiap informasi yang ia terima, sehingga perhatian tidak dapat tertuju pada stimulus secara menyeluruh. Mengenai keaktifan belajar siswa terhadap materi pembelajaran tentang pembelajaran Al-Islam ini dapat dikatakan baik, walaupun ada beberapa dari mereka yang kurang mampu namun dengan upaya menerapkan strategi Think, Talk, Write mengalami perubahan guru selalu memberikan perhatian dan bimbingan intensif kepada mereka agar memiliki pemahaman yang baik dalam belajar Al -Islam.

Kurangnya semangat dan motivasi siswa itu akan menjadi hambatan-hambatan yang akan dihadapi siswa dalam proses belajar mengajar dan kurangnya semangat dari siswa itu bisa diakibatkan karena adanya kejenuhan dalam penyampaian materi, contoh saja seorang guru yang monoton menggunakan metode ceramah terus menerus yang mana siswa hanya sebagai pendengar maka hal itu siswa akan bosan dan akhirnya timbul kejenuhan dan kemalasan dalam belajar, dan dengan upayaupaya yang dilakukan oleh guru di SMP Muhammadiyah Pondok Modern Paciran Lamongan, ini yaitu dengan menerapkan strategi Think, Talk, Write, sebagai salah satu cara untuk menumbuhkan motivasi siswa dalam belajar. Akhirnya dengan menerapkan strategi Think, Talk, Write ini menurut pengamatan dan hasil evaluasi, 
siswa memiliki motivasi yang tinggi dalam mengerjakan tugas-tugas yang diberikan guru. Dengan menumbuhkan kembali semangat dan motivasi yang tinggi bagi siswa ini merupakan suatu upaya yang dilakukan guru untuk meningkatkan keaktifan siswa dalam belajar Al-Islam, sehingga dengan adanya peningkatan pemahaman dan keaktifan ini tujuan-tujuan pengajaran dapat tercapai. ${ }^{22}$

Dengan adanya strategi Think, Talk, Write ini kompetensi dasar dan indikator pencapaian belajar pada siswa akan membawa hasil yang baik karena dalam pelaksanaan pembelajaran menjadi antusias biarpun kadangkala ada juga siswa yang mengalami ketertinggalan dalam belajar namun hal tersebut dapat teratasi dengan menerapkan remedial teaching (perbaikan pengajaran).

\section{Analisis Data}

Proses pengajaran adalah proses pendidikan karena setiap kegiatan pengajaran adalah untuk mencapai tujuan pendidikan. Pengajaran adalah suatu proses aktivitas mengajar dan belajar yang di dalamnya terdapat dua subjek yang saling terlibat, yaitu guru dan peserta didik. Istilah mengajar dan belajar adalah dua peristiwa yang berbeda, akan tetapi antara keduanya terdapat hubungan yang erat, saling mempengaruhi, dan saling menunjang satu sama lain. Secara sederhana mengajar adalah menyampaikan pengetahuan kepada siswa atau peserta didik di sekolah. Mengajar juga berarti suatu usaha untuk mengorganisasi lingkungan sehingga menciptakan kondisi belajar bagi siswa. Pada hakikatnya, kegiatan mengajar adalah suatu kegiatan yang sangat kompleks. Sementara itu, belajar adalah kegiatan yang berproses dan merupakan unsur yang sangat fundamental dalam penyelenggaraan setiap jenis dan jenjang pendidikan. Lebih lanjut dapat dicermati bahwa belajar pada esensinya adalah usaha mengubah diri menjadi lebih baik, melalui proses yang terus menerus. Adanya proses yang panjang dan tertata dengan rapi serta berjenjang akan memungkinkan belajar menjadi lebih baik dan efisien. Sedangkan untuk mendapatkan keaktifan yang integral tentang pengajaran, maka diperlukan teoriteori belajar dan prinsip-prinsip yang mendasari pengajaran, dengan harapan dapat menjadi kontribusi bagi para pembaca dalam memahami dua fondasi dasar proses pengajaran tersebut secara komprehensif. ${ }^{23}$

Menurut Huinker dan Laughlin bahwa strategi membangun secara tepat untuk

\footnotetext{
${ }^{22}$ Interview dengan guru mata pelajaran Al-Islam, Husnul Abid di Paciran Lamongan pada tanggal 29 Juni 2020

${ }^{23} 7$ http://www.Riwayatattubani.blogspot.com/.../teori-teori-dan-prinsip-prinsip.html
} 
berfikir dan merefleksikan dalam mengorganisasikan ide-ide serta mengetes ide tersebut sebelum siswa diminta untuk menulis. Dalam kegiatan pembelajaran AlIslam sering ditemui bahwa ketika siswa diberikan tugas tertulis, siswa selalu mencoba untuk langsung memulai menulis jawaban. Walaupun hal itu bukan sesuatu yang salah, namun akan lebih bermakna jika dia terlebih dahulu melakukan kegiatan berpikir merefleksikan dan menyusun ide-ide, serta menguji ide-ide itu sebelum memulai menulisnya. Untuk itu dalam hal ini peran para pendidik atau guru sangat diperlukan. Dalam mengaktifkan siswa guru harus berusaha untuk memperkuat dan memperlancar stimulus dan respons anak didik dalam pembelajaran, sehingga proses pembelajaran menjadi hal yang menyenangkan, tidak menjadi hal yang membosankan bagi mereka.

Pembelajaran yang aktif hanya bisa terjadi bila ada partisipasi aktif peserta didik, begitu pun juga peran serta aktif peserta didik tidak akan terjadi selama guru tidak aktif dan kreatif dalam melaksanakan pembelajaran karena pada dasarnya proses pembelajaran yang aktif dalam memperoleh informasi, keterampilan dan sikap serta prilaku positif dan terpuji akan terjadi melalui suatu proses pencarian dari diri peserta didik dan hal ini akan terwujud bila peserta didik dikondisikan sedemikian rupa sehingga berbagai tugas dan kegiatan yang dilaksanakan sangat memotivasi mereka untuk berpikir, bekerja, dan merasa serta mengamalkannya dalam kegiatan sehari-hari. ${ }^{24}$ Ada berbagai cara untuk melakukan proses pembelajaran yang memicu dan melibatkan peran aktif peserta didik diantaranya dengan penggunaan strategi Think, Talk, Write.

Menurut pengamatan yang telah dilakukan oleh penulis, bahwa siswa kelas IX SMP Muhammadiyah Pondok Modern Paciran Lamongan Muhammadiyah Paciran Lamongan dapat dikatakan sebagai siswa yang memiliki keaktifan belajar yang cukup baik. Dapat dikatakan demikian karena anak-anak tersebut sudah memenuhi sebagian dari indikator keaktifan belajar. Siswa di kelas IX yang menjadi obyek penelitian, menunjukkan rasa ingin tahu yang besar, hal ini tampak pada antusiasme siswa dalam mengikuti kegiatan belajar mengajar, begitu juga pada guru terlihat berperan aktif dalam memberikan dorongan serta pemberian materi kepada siswa pada saat pembelajaran berlangsung. Ketika guru memasuki kelas, semua siswa duduk ditempat masing-masing dengan tenang. Guru mengucapkan salam dan

\footnotetext{
${ }^{24}$ Ismail, Strategi Pembelajaran Agama Islam Berbasis PAIKEM (Pembelajaran, aktif inovatif, kreatif, efektif dan menyenangkan) (Semarang: Rasail Media Group, 2008), 72
} 
memimpin do'a, kemudian membaca juz amma secara bersama-sama sesuai dengan jadwal. Guru mengevaluasi materi pelajaran yang lalu dan appersepsi tentang kompetisi dan materi yang akan di bahas mula-mula setiap siswa di bentuk menjadi beberapa kelompok, dalam setiap kelompok siswa di haruskan untuk aktif dalam berfikir, berbicara atau berdialog dengan kelompok lain dan kemudian menuliskan hasil diskusinya menurut pendapat masing-masing siswa atau kelompok. Dalam hal ini bisa di lihat antusias siswa dalam hal bertanya, kekompakan dalam berdiskusi dan semua siswa menjawab pertanyaan yang diberikan oleh kelompok lain dengan antusias dan bersemangat.

Dalam kegiatan ini metode yang digunakan adalah bervariasi, yakni metode ceramah, diskusi, praktek, dan Tanya jawab. Metode Ceramah hanya digunakan untuk pengantar saja, selanjutnya dilakukan dengan diskusi dan Tanya jawab serta penugasan. Untuk memahamkan siswa pada bacaan Al-Quran terlebih dahulu guru membacakannya kemudian para siswa menirukan dan membacanya secara bersamasama, setelah membaca bersama-sama guru menunjuk seorang siswa untuk maju kedepan dan membaca setelah itu guru menunjuk salah satu siswa untuk memberikan penilaian kepada temannya yang sudah membaca tadi, hal itu dilakukan secara bergantian. sedangkan untuk memahamkan bacaan tajwid terlebih dahulu guru menerangkan bacaan-bacaan tajwid yang dimaksud (berlangsung selama 25 menit).

Setelah itu guru membentuk kelompok-kelompok yang masing-masing harus dapat mempresentasikan kandungan ayat, bacaan tajwid yang ada dalam ayat tersebut. Setiap kelompok harus aktif dalam kegiatan ini karena nilai siswa didapat dari poin-poin yang diberikan guru pada saat diskusi dan Tanya jawab berlangsung. Diawali dengan presentasi setiap kelompok kemudian para siswa dipersilahkan untuk bertanya dan siapa yang mampu menjawab pertanyaan tersebut akan dapat poin begitu juga dengan siswa yang bertanya mereka juga dapat poin. Setelah itu guru menayakan lagi kepada siswa apakah jawaban dari pertanyaan-pertanyaan yang telah ditanyakan tadi sudah dapat dipahami oleh siswa ataukah belum, jika belum maka guru akan mengulainya lagi, melengkapi jawaban yang telah diberikan siswa tadi. Tetapi apabila sudah paham, maka guru tidak perlu mengulagi jawaban tadi (kurang lebih berlangsung selama 30 menit). Dengan adanya metode yang digunakan secara bervariasi dan adanya strategi tersebut, dapat membuat siswa menjadi interaktif dan aktif dalam kegiatan belajar mengajar, serta dengan adanya 
metode yang bervariasi tersebut siswa lebih antusias, bersemangat, aktif dalam bertanya dan menjawab pertanyaan, serta mengungkapkan pendapat sendiri sehingga yang terlihat suasana pembelajaran menjadi interaktif dan menyenangkan dan tidak membosankan, karena diselingi pula dengan humor-humor kecil dari para siswa. Hal ini diperjelas oleh Bapak Husnul Abid, selaku guru mata pelajaran Al-Islam di SMP Muhammadiyah Pondok Modern Paciran Lamongan yang menyatakan bahwa: "Factor penunjang dalam meningkatkan keaktifan belajar siswa yaitu dengan adanya penggunaan berbagai macam metode pembelajaran serta adanya latihanlatihan dalam suatu pengajaran, akan tetapi jika hal tersebut tidak ada maka akan menghambat keaktifan yang mereka miliki”.

Faktor-faktor yang mendukung keaktifan belajar siswa dalam pengajaran, ada dua hal yaitu dorongan yang berasal dari dalam dan dorongan dari luar. Dorongan yang berasal dari dalam yaitu berasal dari dalam individu itu sendiri, namun membutuhkan kondisi yang tepat untuk mengekspresikan, sedangkan dorongan yang berasal dari luar yaitu berasal dari lingkungan sekitar yang dapat mengembangkan dan mengasah keaktifan anak. Sedangkan ciri-ciri keaktifan belajar dapat diidentifikasikan sebagai berikut:

a. Adanya keterlibatan siswa dalam menyusun atau membuat perencanaan, proses belajar mengajar dan evaluasi.

b. Adanya keterlibatan intelektual-emosional siswa baik mengalami, menganalisa, berbuat dan pembentukan sikap.

c. Adanya keikutsertaan siswa secara kreatif dalam menciptakan situasi yang cocok untuk berlangsungnya proses belajar mengajar.

d. Guru bertindak sebagai fasilitator dan coordinator kegiatan belajar siswa, bukan sebagai pengajar (instruktur) yang mendominasi kegiatan dikelas.

e. Biasanya menggunakan berbagai metode secara bervariasi, alat dan media pengajaran. Semakin banyak ciri yang dimiliki dalam suatu proses pengajaran, semakin tinggi pula kadar keaktifan belajar siswa. ${ }^{25}$

Dengan adanya Strategi Think, Talk, Write, akan diperoleh manfaat sebagai berikut:

a. Bahan pembelajaran akan lebih jelas maknanya karena adanya keharusan siswa untuk aktif dalam berdiskusi sehingga siswa lebih dapat memahami dan

${ }^{25}$ Muhammad Ali, Guru dalam Proses Belajar Mengajar, 68-69 
memungkinkannya menguasai dan mencapai tujuan belajar.

b. Siswa dapat lebih banyak melakukan kegiatan belajar sebab tidak hanya mendengarkan uraian guru, tetapi juga aktivitas lain seperti mengamati, melakukan, mendemonstrasikan dan lain-lain.

c. Pembelajaran akan lebih menarik perhatian siswa karena adanya metode mengajar yang bervariasi sehingga meningkatakan motivasi dan keaktifan belajar siswa.

Dalam kegiatan akhir, guru bersama siswa menyimpulkan isi kandungan "QS Al-Kafirun: 1-6, QS yunus: 40-41, dan Al-kahfi: 29, sebagai ulangan terhadap pengajaran yang telah dilakukan agar siswa lebih faham dan tidak lupa. Kemudian setelah itu guru memberi pekerjaan rumah atau tugas kepada siswa mengerjakan latihan-latihan yang ada di buku paket serta menghafalkan ayatnya.

Berdasarkan hasil observasi tersebut, penulis menyimpulkan bahwa siswa kelas IX SMP Muhammadiyah Pondok Modern Paciran Lamongan memang dapat dikatakan sebagai siswa yang memiliki keaktifan belajar yang cukup baik, karena siswa tersebut telah memenuhi sebagian dari indicator keaktifan belajar siswa, antara lain dari segi siswa:

a. Keinginan, keberanian menampilkan minat, kebutuhan dan permasalahan yang dihadapinya.

b. Keinginan dan keberanian siswa serta kesempatan untuk berpartisipasi dalam kegiatan persiapan, proses dan kelanjutan belajar.

c. Siswa dapat menampilkan berbagai usaha atau kekreatifan belajar dalam menjalani dan menyelesaikan kegiatan belajar sampai mencapai keberhasilannya.

d. Kemandirian belajar.

Secara umum dalam proses pembelajaran, keaktifan merupakan sesuatu yang penting dan bermanfaat bagi pendidikan. Hal ini dikarenakan siswa yang dibekali dengan pemikiran yang aktif akan dapat menghadapi kompleksitas kehidupan pada masanya. Berdasarkan pengamatan (observasi) dan interview yang telah dilakukan oleh penulis, dapat disimpulkan bahwa pelaksanaan Strategi Think,Talk,Write, memiliki peran dalam meningkatkan keaktifan belajar siswa dalam kegiatan belajar mengajar, terutama dalam mata pelajaran Al-islam. Adapun implementasi dari Strategi Think, Talk, Write, dalam meningkatkan keaktifan belajar siswa adalah dengan adanya proses pembelajaran aktif yang dimulai dari aktif berfikir melalui 
membaca, berdialog atau berdiskusi dan menuliskan hasil diskusinya dengan menggunakan bahasanya sendiri. Yang dilakukan oleh guru dalam menyampaikan materi pelajaran yang ditunjang dengan penggunaan beberapa metode pengajaran yang bervariasi akan dapat memotivasi siswa dalam belajar, membuat siswa lebih memperhatikan dalam belajar, membantu proses pembelajaran interaktif menyenangkan antara guru dan murid, sehingga meningkatkan keaktifan belajar siswa dan memudahkannya dalam menerima materi pelajaran.

Dengan adanya penggunaan Strategi Think, Talk, Write ini, diharapkan dapat melatih siswa untuk mengkontruksikan pengetahuannya sendiri sehingga pemahaman siswa menjadi lebih baik, sehingga dapat mencapai tujuan pembelajaran yang diinginkan yaitu tercapainya tujuan pembelajaran Al-islam, karena pada dasarnya strategi ini mengajak siswa agar dalam belajar siswa tidak hanya duduk dan mendengarkan saja akan tetapi siswa harus membaca, berfikir, berkomunikasi (berbicara)dan menyimpulkan, maka akan dapat meningkatkan kemungkinan mereka untuk semakin mampu mengingat dan menyimpan informasi yang sudah diberikan. Untuk itu yang terbaik bagi guru Al-islam adalah menambah latihan pelajaran Al-Islam dalam berbagai cara yang berbeda, seperti dengan penggunaan metode dan stategi yang bermacam-macam.

\section{B. KESIMPULAN}

Dari Penelitian ini dapat ditarik kesimpulan sebagai berikut : Pertama, Strategi Think, Talk, Write di terapkan di SMP Muhammadiyah Pondok Modern Paciran lamongan dengan cara membentuk kelompok-kelompok yang masingmasing harus dapat mempresentasikan kandungan ayat, bacaan tajwid yang ada dalam ayat tersebut. Setiap kelompok harus aktif dalam kegiatan ini karena nilai siswa di dapat dari poin-poin yang diberikan guru pada saat diskusi dan Tanya jawab berlangsung. Adapun penerapan strategi ini tidak mengalami problem atau kendala yang berarti, strategi Think, Talk, Write sudah memberi hasil yang sangat memuaskan, di samping itu strategi ini juga menggunakan beberapa metode diantaranya ceramah, Tanya jawab, dan lain-lain dalam proses pembelajaran. Kedua, dengan menggunakan strategi Think, Talk, Write dapat di katakana bahwa keaktifan belajar siswa sudah Baik, karena anak-anak tersebut sudah memenuhi sebagian dari indikator keaktifan belajar, lebih antusias dan lebih bersemangat. 


\section{DAFTAR PUSTAKA}

Arikunto, Suharsimi (2006), Prosedur Penelitian Suatu Pendekatan Praktik, Jakarta: Rineka Cipta.

Arsyad, Azhar (2007), Media Pembelajaran, Jakarta: Raja Grafindo Persada.

Bakry, Sama'un (2005), Menggagas Konsep Ilmu Pendidikan Islam, Bandung: Pustaka Bani Quraisy.

Bobbi, De Porter dan Mike Hermaeki (2002), Quantum learning, Bandung: Kaifa.

Dimiyati (1999), Belajar dan pembelajaran, Jakarta: Rineka Cipta.

Djamarah, Syaiful Bahri (1995), Strategi Belajar Mengajar, Jakarta : Rineka Cipta.

Furhan, Arief (1982), Pengantar Penelitian Dalam Pendidikan, Surabaya: Usaha Nasional.

Hadi, Sutrisno (1991), Metodologi Research II, Yogyakarta: Andi Offset.

Hasbullah (2003), Dasar-Dasar Ilmu Pendidikan, Jakarta: Raja Grafindo Persada.

Hisyam, Zaini dkk (2007), Strategi Pembelajaran Aktif, Yogyakarta: CTSD.

Ismail, Strategi Pembelajaran Agama Islam Berbasis PAIKEM (Pembelajaran, aktif inovatif, kreatif, efektif dan menyenangkan), Semarang: Rasail Media Group.

Moleong, Lexy J (2007), Metodologi Penelitian Kualitatif, Bandung: Remaja Rosda Karya.

Nasution (2006), Metode Reseach, Jakarta: Bumi Aksara.

Najib, Sulhan (2006), Pembangunan Karakter Pada Anak, Manajemen Pembelajaran Guru Menuju Sekolah Efektif, Surabaya: Intelektual Clib.

Silberman, Melvin (2004), Active Learning, Bandung: Nusa Media.

Suriasumantr, Jujun (1994), Filsafat Ilmu: Sebuah Pengantar Popular, Jakarta: Pustaka Sinar Harapan.

Surakhman, Winarno (1998), Pengantar Ilmiyah Dasar Metode Tehnik, Bandung: Tarsito. 
Suwarno, Wiji (2006), Dasar-Dasar Ilmu Pendidikan, Yogyakarta: AR-RUZZ Media.

Taboni, Imam Suprayogo (2001), Metodologi Penelitian Sosial Agama, Bandung: Remaja Rosda Karya. 